\title{
PENGGEMBALAAN YANG EFEKTIF BAGI GENERASI MILENIAL DI ERA SOCIETY 5.0
}

\author{
Joni Manumpak Parulian Gultom \\ (Dosen Prodi Teologi STT REAL Batam; jonimanumpakgultom@gmail.com)
}

\begin{abstract}
The results of the Barna Institute stated that 57\% of children aged 18-29 years did not regularly worship. While a survey from Number Research in the age range of 15-18 years, adolescents who do not usually worship are 7.7\%. That increased to $10.2 \%$ at the age of 19-22 years and reached $13.7 \%$ at this age of 23-25 years. Their level of concern for God and worship decreased drastically. The local church lost its way of shepherding them. Shepherd stewardship did not develop linearly with the development of social media. How should shepherd be? What strategies are used be in face-to-face pastoral care and virtual spaces? This paper aims to restore the quality of pastoring function and bridge the local church pastoring caretaker with the virtual world. The research method used is a qualitative method with literature study and observation. This research hoped to maximize the shepherding and discipleship of millennial children. So that millennial children experience spiritual growth, remain committed to shepherding, and contribute to local and virtual services on an ongoing basis.
\end{abstract}

Keywords: milenial generation, pastoring, onsite, virtual, ministry

\section{A. PENDAHULUAN}

Perkembangan masif media sosial telah mempengaruhi terjadinya krisis kepemimpinan penggembalaan gereja local. Kejadian ini membuka mata dan pikiran kepada pemimpin gereja akan sebuah tantangan berat dalam misi penjangkaun anak milenial Kristen. Penggembalaan dan mentoring dari gereja secara onsite hampir terputus, dan penjangkauan kepada generasi ini dalam ruang digital juga tidak maksimal, terkhusus dengan kejadian pandemi Covid-19. Bilangan Research Center mengadakan survey terhadap 4.095 anak remaja tahun 2018. Data hasil menunjukkan bahwa 61,8\% generasi milenial menyatakan bahwa gereja tidak menarik dan tidak cocok dengan mereka.

Prosentase yang beribadah memang berkisar di $91.8 \%$ namun yang benar benar menyadari arti ibadah itu sendiri hanya $19,4 \%$. Satu dari tiga remaja Kristen yang rajin beribadah punya potensi untuk tidak melakukannya lagi. ${ }^{1}$ Perhatian khusus terletak kepada yang rutin melakukan ibadah hanya sekitar 68,4\%, di mana 12,1\% anak umur 15-24 tahun dan 10,8\% yang berumur 25-39 tahun justru tidak beribadah sama sekali. Walaupun platform media virtual sangat masif di kalangan anak milenial, namun hanya 49,3\% yang menggunakannya secara rutin. ${ }^{2}$ Sedangkan hasil terbaru BRC indeks spiritual Kekristenan 2021 sendiri berada diangka moderat yaitu 3,79. Angka ini sangat mungkin mengalami koreksi negatif di masa datang khususnya untuk anak milenial.

${ }^{1}$ Cemara A. Putra Handi Irawan D, "Gereja Sudah Tidak Menarik Bagi Kaum Muda, [The Church Is Not Attractive To Young People]," Bilangan Research Center, last modified 2018, accessed July 31, 2021, http://bilanganresearch.com/gereja-sudah-tidak-menarik-bagi-kaum-muda.html.

${ }^{2}$ Handi Irawan, "Spiritualitas Umat Kristen Indonesia 2021," Bilangan Research Center (Jakarta, 2021). 
Data lain menunjukkan bahwa sebanyak 36.5\% anak muda tidak rutin membaca Alkitab, dan bahkan 4,6\% di antaranya tidak pernah membaca Alkitab. ${ }^{3}$ Keadaan ini menimbulkan hambatan pertumbuhan iman, sebab hal-hal yang spiritual tidak begitu menarik perhatian mereka. ${ }^{4}$ Demografi penduduk generasi milenial merupakan prosentase terbesar jumlah jiwa dalam gereja, namun dalam keadaan yang bersamaan generasi milenial sedang berada dalam keterikatan yang sangat kuat dengan kemajuan teknologi dan media social. ${ }^{5}$ Dalam beberapa kasus secara sadar generasi milenial telah mengganggap "dunia digital” ini sebagai agama baru. ${ }^{6}$

Tingkat pertumbuhan rohani generasi ini menurun tajam hampir diseluruh pelayanan gereja lokal di kota besar, hal ini dikarenakan karakteristiknya yang sangat kontemporer, kotradiksi dengan keberadaan gereja yang konservatif. ${ }^{7}$ Perubahan dari era Industri 4.0 ke era society 5.0 memberikan konsep kepada masyarakat digital tentang mobilitas tinggi dengan keamanan dan tingkat hidup yang berkualitas. Masyarakat dipermudah untuk memenuhi kebutuhannya melalui teknologi. Penekanan yang paling krusial adalah bagaimana Internet of Things dapat menciptakan nilai nilai baru yang dapat memberi solusi kehidupan sosial dan segala turunanannya kepada manusia. ${ }^{8}$ Era ini juga menjanjikan jawaban dan jalan keluar yang rinci untuk berbagai kebutuhan komunitas terlepas dari wilayah, umur, jenis kelamin, bahasa bahkan kepada penyediaan jasa dan penatalayanan. Karena realisasi dari hal-hal di atas ini adalah dengan memadukan ruang cyber dengan dunia nyata dalam menciptakan menciptakan nilai-nilai dan terobosan terobosan baru untuk menyelesaikan tantangan. ${ }^{9}$

Team pastoral harus sesegera mungkin membuat strategi pelayanan dengan penerapan berbeda lewat kombinasi pelayanan melalui tatap muka dan virtual dalam era society 5.0. Kualitas dan kuantitas penggembalaannya mau tidak mau harus lebih baik daripada waktu sebelumnya. Sebab jika tidak ada strategi baru maka gereja mengalami kehilangan sebagian besar dari generasi milenial Kristen. Dan keadaan ini sangat mungkin mungkin berlaku sampai kepada generasi generasi selanjutnya. Penggembalaan Gereja harus dapat menyesuaikan diri antara penatalayanan tatap muka

\footnotetext{
${ }^{3}$ Joni Manumpak Parulian Gultom et al., "Generasi Millenial Dan Kaitan Tugas Yeremia Dalam Kegerakan Pantekosta," Real Didache 4, no. 1 (2019): 12-25.

${ }^{4}$ Yonatan Alex Arifianto, Sari Saptorini, and Kalis Stevanus, "Pentingnya Peran Media Sosial Dalam Pelaksanaan Misi Di Masa Pandemi Covid-19," Harvester 5, no. 2 (2020): 86-104.

${ }^{5}$ Amelia Kimberlyann Rumbiak, "Teologi Ibadah Dan Spiritualitas Generasi Milenial," Amreta 3, no. 2 (2020): 64-100.

${ }^{6}$ Ibid. 134.

${ }^{7}$ Yanua Surya Putra, "Teori Perbedaan Generasi," Among Makarti 9, no. 18 (2016): 123 -

${ }^{8}$ M Hidayat, "Ini Perbedaan Revolusi Industri 4.0 Dengan Society 5.0," Liputan6.Com, last modified 2020, accessed July 31, 2021, https://www.liputan6.com/tekno/read/4408526/ini-perbedaanrevolusi-industri-40-dengan-society-50.

${ }^{9}$ Ni Ketut Erna Muliastrini2 Ni Nyoman Lisna Handayanil, "Pembelajaran Era Disruptif Menuju Era Society 5.0 (Telaah Perspektif Pendidikan Dasar) Ni," International Seminar Proceeding 3, no. 2252 (2020): 58-66.
} 
dengan budaya digital dan media yang tetap memberi penguatan nilai kemanusiaan. ${ }^{10}$ Team Pastoral gereja lokal bertanggung jawab penuh terhadap perubahan terjadi dalam kegiatan menggereja. Hal ini disebabkan karena pengaruh negatif dalam komunitas dan pola komunikasi generasi ini di dunia digital. Kemajuan Teknologi Informasi dan media cenderung sangat berbahaya dan sangat mempengaruhi logika berpikir dan dunia maya tanpa Tuhan. ${ }^{11}$

Pertanyaannya adalah apa saja nilai penggembalaan yang mengalami penyesuaian standar pelayanan kekinian? Serta strategi seperti apa yang dilakukan oleh team penggembalaan, baik dalam bentuk pelayanan tatap muka dan pada ruang virtual? Apa bentuk dan praktik nyata untuk dikerjakan dalam peningkatan kehidupan kerohanian mereka? Tujuan penulisan ini adalah untuk memaksimalkan fungsi penggembalaan yang berkualitas sesuai Alkitab dan menjembatani penatalayanan penggembalaan gereja lokal dan dunia virtual.

Argumen Penelitian bahwa penggembalaan jangan kaku untuk melakukan transisi pelayanan dari ruang tradisional tatap muka ke dalam ruang virtual melalui kombinasi strategi penatalayanan kekinian. Rancang bangunnya adalah dengan menjembatani komunikasi verbal dan praktek kepemimpinan generasi milenial. Hal selanjutnya dengan pendekatan pelayanan dengan membuka ruang kolaborasi serta penggunaan ruang virtual sebagai strategi terobosan penggembalaan.

Diharapkan penggembalaan dapat memaksimalkan pelayanan kepada anak milenial, sehingga mengalami pertumbuhan rohani, tetap komitmen dalam penggembalaan dan berkontribusi dalam pelayanan lokal dan virtual secara berkelanjutan di era Society 5.0 ini.

\section{B. METODOLOGI}

Metodologi penelitian adalah metode kualitatif dengan pengambilan data melalui studi literatur dan observasi. Data dari observasi ini sesuai dengan penelitian ilmu sosial yang melihat data secara natural dalam kehidupan manusia tanpa memerlukan adanya kategori tertentu dan tanggapan awal yang telah diperkirakan. ${ }^{12}$ Mulawarman dalam penelitiannya mendapatkan konsep konsep yang baru dari pengalaman yang bisa muncul secara tiba-tiba. ${ }^{13}$ Observasi yang lakukan adalah dengan observasi partisipan dimana peneliti turut bergabung ke dalam komunitas anak milenial di acara pertemuan ibadah maupun kelas pemuridan yang diadakan. Hal ini untuk dapat mengamati secara langsung tingkat keterbukaan, ketertarikan mereka dengan melibatkan seluruh panca indera dalam ruangan virtual dan juga tatap muka. Seluruh kekuatan indera seperti pendengaran, penglihatan,

${ }^{10}$ Lenda Dabora J F Sagala, “Tugas Pedagogis Gembala Dalam Menyiapkan Warga Gereja Menghadapi Perubahan Sosial," Evangelikal: Jurnal Teologi Injili dan Pembinaan Warga Jemaat 4, no. 2 (2020): 167-174.

${ }^{11}$ Ibid.

${ }^{12}$ Hasyim Hasanah, "Teknik-Teknik Observasi," at-Taqaddum 8, no. 1 (2016): 21-46.

${ }^{13}$ Mulawarman and Aldila Dyas Nurfitri, "Perilaku Pengguna Media Sosial Beserta Implikasinya Ditinjau Dari Perspektif Psikologi Sosial Terapan," Buletin Psikologi 25, no. 1 (2017): $36-44$. 
perasa, sentuhan, dan cita rasa berdasarkan pada fakta-fakta peristiwa empiris, mendasarkan pada gejala-gejala umum, kejadian atau fenomena sosial, pola-pola, dan tipe perilaku tertentu. ${ }^{14}$ Penelitian ini diharapkan dapat memaksimalkan penggembalaan anak milenial sejak dini dan dapat merespon panggilan pelayanan yang terjadi dengan menggunakan teknologi media yang sudah ada.

\section{PEMBAHASAN}

Penggembalaan merupakan panggilan mendasar dari gereja Tuhan sejak Pentakosta. Tugas ini adalah kerinduan dari Tuhan untuk jiwa jiwa mengalami kedewasaan rohani sesuai dengan pertumbuhan iman. ${ }^{15}$ Ada beberapa tingkatan dalam tugas penggembalaan ini. Pertama adalah memelihara jiwa jiwa (1 Pet 5:1-4), digambarkan bagaimana Allah menjaga jemaat-Nya agar tidak jatuh ke dalam kesesatan dunia. Tugas ini yang menjadi fokus para gembala dan pemimpin gereja Tuhan seutuhnya. ${ }^{16}$ Kriteria yang mengikuti adalah tanggung jawab dengan sungguh sungguh dan ketulusan melayani. Hal kedua adalah mengajar dan memuridkan.

Pemuridan ini menjadi bagian dalam penjangkaun jiwa selain proses pembentukan karakter. ${ }^{17}$ Mereka menjadi berkat dalam komunitas yang terdiri dari berbagai budaya dengan kasih Kristus. ${ }^{18}$ Ini menjadi hal yang penting dalam mempersiapkan mereka untuk pertumbuhan menuju kedewasaan rohani, baik mengambil bagian melayani dan juga menjadi alat bagi kemuliaan Tuhan. Penggembalaan bukanlah membuat manusia menjadi lebih baik ataupun pengembangan diri saja, namun hidup menjadi seperti Yesus Kristus, mengalami perubahan yang transenden dan memuliakan Tuhan dalam seluruh kehidupannya.

Penggembalaan Gereja harus dapat menyesuaikan diri antara penatalayanan tatap muka dengan budaya digital dan media yang tetap memberi penguatan nilai kemanusiaan. ${ }^{19}$ Sedangkan tugas penggembalaan yang tak kalah penting lainnya adalah menjadi contoh dan teladan (Fil 3:17; 2 Tes 3:9;1 Pet 5:3). Team pastoral memberikan nilai keteladanan yang dapat diikuti oleh jiwa jiwa dalam pertumbuhan kerohanian yang berlanjut dan berkesinambungan. David Kinnaman menulis dalam bukunya generasi ini seperti sudah terhilang meskipun masih dalam lingkup gereja. Mereka seperti terasing dan berpindah pindah dengan segala info yang masuk tanpa disaring. Sehingga mereka menjadi tidak terkoneksi dengan lembaga gereja dan penggembalaan yang ada.

\footnotetext{
${ }^{14}$ Hasanah, "Teknik-Teknik Observasi."

${ }^{15}$ Magdalena, Yanto Paulus Hermanto, and Ferry Simanjuntak, “Gereja Yang Bertumbuh Tanpa Baalisme," Voice Of Wesley 4, no. 2 (2019): 11-23.

${ }^{16}$ Sara L Sapan and Dicky Dominggus, "Tanggung Jawab Penggembalaan Berdasarkan Perspektif 1 Petrus 5: 1-4” 3, no. 2 (2020): 1-4.

${ }^{17}$ Magdalena, Hermanto, and Simanjuntak, "Gereja Yang Bertumbuh Tanpa Baalisme."

${ }^{18}$ I Putu Ayub Darmawan, “Jadikanlah Murid: Tugas Pemuridan Gereja Menurut Matius 28:18-20," Evangelical 3, no. 2 (2019): 144-153.

${ }^{19}$ Sagala, "Tugas Pedagogis Gembala Dalam Menyiapkan Warga Gereja Menghadapi Perubahan Sosial."
} 
Gereja terlalu menjaga dirinya sendiri tanpa memperdulikan keberadaan mereka, dangkal dalam melihat kondisi dan solusi, sehingga menekan dengan berlebihan. Akibat yang paling terlihat adalah gereja dan team penggembalaan menjadi eksklusif dan meragukan kemampuan anak milenial. ${ }^{20}$ Firman Tuhan tetap menjadi standar keputusan penatalayanan dalam penggembalaan. Setiap kemajuan, konsistensi dan ketahanan gembala atau pemimpin gereja lokal dalam kehidupan sehari hari, memberi impikasi penting bagi praktek kehidupan keteladanan dan kualitas nyata dari di kehidupan sehari-hari. Hal inilah yang ingin disaksikan, diperdengarkan dan juga di bagikan kepada generasi milenial.

\section{Jembatan Komunikasi Verbal dan Praktek Kepemimpinan Kekinian}

Langkah awal strategi menjembatani komunikasi verbal penggembalaan adalah dengan proklamasi dan pernyataan iman dan fokus penatalayanan secara jelas kepada anak milenial. Hal ini dinyatakan dalam pernyataan bersama gembala dan team kepemimpinan gereja lokal secara formal dalam bentuk visi dan misi. Konsensus bersama ini dipaparkan dalam moment penting, seperti ulang tahun gereja, awal tahun, Paskah dan lain lain dalam kegiatan gereja lokal. Di perlukan kordinasi lengkap, penyamaan visi dan misi serta langkah kordinasi yang kontinyu diantara team penggembalaan. Setiap langkah dan program gereja seperti kelas kepemimpinan, bible study, seminar dan pelatihan adalah sebagai bentuk nyata dari penjabaran visi dan misi dengan tujuan akhir untuk melahirkan kepemimpinan generasi milenial. Oleh sebab itu setiap pertemuan tatap muka kepada generasi milenial sudah menjadi kewajiban dan komitmen tinggi dengan jadwal yang telah ditentukan serta tanpa diwakilkan. Team pastoral mengurangi jadwal undangan pendeta dan pelatih dari luar gereja sementara waktu.

Garda depan strategi yang harus dirubah adalah membangun dan memperbaiki jembatan komunikasi sehingga menjadi efektif. Wulan Sari menyatakan bahwa komunikasi ini sesuatu yang sederhana tapi justru menjadi kendala besar antar individu dalam komunitas yang besar. Membangun komunikasi yang efektif, setidaknya kita harus: (1) Berusaha benar-benar mengerti orang lain (emphatetic communication), (2) Memenuhi komitmen atau janji, (3) Menjelaskan harapan atau rencana yang akan di lakukan, (4) Meminta maaf dengan tulus ketika membuat kesalahan, (5)

${ }^{20}$ David Kinnaman and Aly Hawkins, You Lost Me, Why Young Christians Are Leaving Church and Rethinking Faith (Michigan: Baker Books, 2011), https://www.yumpu.com/en/document/view/64143544/download-pdf-you-lost-me-why-youngchristians-are-leaving-church-and-rethinking-faith-full-online/3. 
Memperlihatkan integritas pribadi. ${ }^{21}$ Sedangkan Sutaryo menjelaskan dalam bukunya kata komunikasi berarti pergaulan, pemberitahuan, dan perhubungan. ${ }^{22}$

Dari pengertian di atas komunikasi kepemimpinan yang dibangun oleh team penggembalaan bukan saja sebagai pihak dari kepemimpinan gereja namun dapat memposisikan sebagai keluarga ilahi dalam ikatan kasih yang tulus dan murni. Sehingga menjadi tugas tersendiri untuk mengkomunikasikan, (1) apa yang sedang dipikirkan, (2) Apa yang dikatakan dan (3) apa yang sedang kita lakukan kepada generasi milenial berkaitan dengan visi dan misi Allah. Semakin tinggi tingkat kedalaman dan keterjalinan komunikasi yang terjadi dalam proses tatap muka, semakin besar pengaruh kepemimpinan itu untuk ditransferkan kepada mereka. Target yang ingin dicapai adalah bahwa gereja dan team penggembalan dengan penatalayanan yang dibuat bisa dipercayai oleh anak milenial.

Pertemuan tatap muka harus mengalami pembaharuan dalam segi waktu, metode dan juga langkah pendekatan. Segala sesuatu yang dilakukan secara terus menerus dan berulang ulang dalam jangka waktu yang relatif lama tanpa sebuah perubahan sesuai dengan zaman akan menjadikan ibadah dan pertemuan rohani kehilangan makna. Ini yang disebut sebagai istilah Ritual tanpa Spiritual. ${ }^{23}$ Gereja jangan hanya berfungsi sebagai tempat berkumpul tanpa titik kekekalan. Dalam survey yang dilakukan di Denmark dan Norwegia dimana hanya kurang dari 4-5\% anak milenial yang beribadah seminggu sekali. ${ }^{24}$ Berbeda dengan kasus di Amerika, dimana sekitar $43 \%$ anak milenial yang bisa 3-4 kali ke gereja selama seminggu.

Bilangan Research Center di Indonesia mencatat ada kenaikan hampir $100 \%$ jumlah remaja yang tidak rutin beribadah (dari usia 15-18 tahun sebanyak 7,7\%, meningkat saat umur 19-22 tahun menjadi 10,25 dan puncaknya 23-25 tahun menjadi 13,7\%). Alasan terjadi penurunan generasi milenial dalam gereja lokal dikarenakan penyajian kotbah yang tidak menarik, tidak relevan dengan kehidupan mereka dan hal yang kedua adalah tidak tersedianya kesempatan anak milenial untuk melayani sampai jenjang yang lebih tinggi. ${ }^{25}$

Penggembalaan memiliki nilai kasih yang tinggi, yang terimplementasi dalam penyajian Firman Tuhan. Tunjukkan bahwa generasi milenial menjadi target yang besar untuk diselamatkan.

${ }^{21}$ Ambar Wulan Sari, "Pentingnya Ketrampilan Mendengar Dalam Menciptakan Komunikasi Yang Efektif," Jurnal EduTech 2, no. 1 (2016): 1-10, http://jurnal.umsu.ac.id/index.php/edutech/article/view/572.

${ }^{22}$ Sutaryo, Sosiologi Komunikasi, Universitas Terbuka (Jakarta: Universitas Terbuka, 2005), http://repository.ut.ac.id/4614/2/SOSI4402-M1.pdf.

${ }^{23}$ Bigman Sirait, "Ritual Tanpa Spritual," Reformata, last modified 2015, https://reformata.com/news/view/370/ritual-tanpa-spritual.

${ }^{24}$ Marianne Nilsen Kvande, Christian Andreas Klöckner, and Michael E Nielsen, "Church Attendance and Religious Experience : Differential Associations to Well- Church Attendance and Religious Experience : Differential Associations to Well-Being for Norwegian Women and Men ?," no. November (2015): 1-13.

${ }^{25}$ Handi Irawan D, "Gereja Sudah Tidak Menarik Bagi Kaum Muda, [The Church Is Not Attractive To Young People]." 
Pemimpin tertinggi perlu memberikan instruksi mendesak kepada para pemimpin lainnya, untuk memberi prosentase besar dalam kotbah dan renungan bagai generasi mielnial. Komitmen yang berkesinambungan untuk diperdengarkan dan dinyatakan secara langsung dalam pertemuan penting, dan ibadah yang disaksikan oleh seluruh jemaat lokal. Namun bukan hanya menyampaikan materi, tetapi nilai -nilai dari isi kotbah dan renungan ini pun sudah menjadi bagian integral dari gembala dan pemimpin untuk konsisten menunjukkan keteladanan dan keseriusan membawa visi misi Allah untuk anak milenial.

Kotbah untuk generasi milenial adalah kejujuran dan nilai keteladanan. ${ }^{26}$ Namun kotbah penggembalaan kurang mempengaruhi karena generasi ini tidak mampu membentengi dirinya dari pertempuran racun dan oksidan kehidupan sehari-hari. Pendidikan agama dan spiritual sudah teracuni dengan hal buruk akibat kemajuan media sosial dan komunitas virtualnya. ${ }^{27}$ Dunia teknologi telah menjadikan agama dan penatalayan menjadi seperti terpisah. Padahal seharusnya kemajuan dalam dunia teknologi menjadi sebuah sarana untuk adaptasi penatalayan rohani dalam segmen yang baru yang berhadapan dengan pola pemahaman generasi yang dianggap seperti menyimpang. ${ }^{28}$ Anak milenial memang memiliki kognitif revisioner yang sepertinya tidak dapat diterima oleh gereja. Mereka perlu kasih tulus untuk diterima oleh siapapun mereka. ${ }^{29}$

Team Penggembalaan gereja lokal harus menjadi pribadi pribadi yang dipercaya. Dari hasil survey Bilangan Research Center, tingkat kepercayaan generasi milenial sangat rendah kepada gereja, sehingga menjadi kendala besar dalam penatalayan pengggembalaan. ${ }^{30}$ Generasi ini sangat mudah terbuka namun teledor dengan menjaga rahasia mereka. ${ }^{31}$ Penggembalaan gereja lokal terbuka dan terbeban dengan masa depan rohani mereka. Persiapkan materi-materi kotbah atau renungan yang berkaitan dengan visi misi Firman Tuhan bagi anak milenial dalam panggilan Sorga (Ams 22:15, 29:15). Tarigan menyatakan bahwa penggembalaan generasi milenial adalah target utama, mereka merupakan subjek penjangkaun jiwa bagi Kristus untuk melayani Kerajaan Sorga. ${ }^{32}$

\section{${ }^{26}$ Talizaro Tafonao, "Yesus Sebagai Guru Teladan Dalam Masyarkat Berdasarkan} Perspektif Injil Matius," Khazanah Theologia 2, no. 1 (2020): 52-60.

${ }^{27}$ Alexandru Gabriel Negoita, "Religiosity In The Contemporary World," Euromentor X, no. 3 (2019): 27-38.

${ }^{28}$ Abby Day, Religion and the Individual: Belief, Practice, Identity, Religion and the Individual: Belief, Practice, Identity, 2016.

${ }^{29}$ Andrew Root, "Stop Worrying about the Millennials*:*and Learn to Love Them Instead," Christianity Today 59, no. 1 (2015): 30-36.

${ }^{30}$ Handi Irawan D, “Gereja Sudah Tidak Menarik Bagi Kaum Muda, [The Church Is Not Attractive To Young People]."

${ }^{31}$ Ester, "Mengenal Generasi Millennial," Kementerian Informasi Dan Informatika Republik Indonesia, last modified 2016, https://www.kominfo.go.id/content/detail/8566/mengenal-generasimillennial/0/sorotan_media.

${ }^{32}$ Sayang Tarigan, Yanto Paulus Hermanto, and Nira Olyvia, "Kepemimpinan Tuhan Yesus Di Masa Krisis Sebagai Model Kepemimpinan Kristen Saat Ini," Teologi dan Kepemimpinan Kristen 6, no. 1 (2021): 38-54. 
Terobosan terobosan baru diambil team penggembalaan sepert minimal satu minggu dalam sebulan kotbah Minggu spesial untuk generasi milenial. Terobosan lainnya dengan mendoakan mereka setelah Perjamuan Kudus. Team pastoral bersama seluruh orang tua serta jemaat berdoa mengurapi mereka. Ini sebagai bentuk dukungan dan keunitian bergerak bersama dalam panggilan Tuhan. Generasi milenial seharusnya juga sudah menjadi kebanggaan dalam pelayanan gereja lokal sekarang ini. Jumlah populasi mereka memiliki prosentase yang besar di seluruh dunia. ${ }^{33}$ Sudah selayaknya dan seharusnya bagaimana anak milenial menjadi fokus strategi pelayanan utama dalam gereja untuk menjadikan mereka garam dan terang bagi komunitas terbesar di dunia dan menjadi tongkat estafet dalam pelayanan gereja di masa datang. Hal ini dikatakan oleh Paulus dalam 2 Korintus 3:3 bahwa jemaat telah menjadi suratan Kristus yang ditulis oleh pelayanan kami. Generasi milenial sudah menjadi sebuah ketentuan gereja lokal untuk menjadi target dan fokus utama dalam pelayananan penggembalaan dalam ibadah tatap muka yang ada di gereja lokal.

\section{Pendekatan Pelayanan; Memberi Ruang Untuk Berkolaborasi}

Strategi penting lainnya bagaimana gereja lokal memberikan mimbar atau panggung kesempatan melayani sejak dini kepada generasi ini. Langkah awal adalah membuka banyak kelas kelas persiapan untuk melayani seperti kelas orientasi melayani, kelas permuridan (mentoring) dan kelas kepemimpinan selain khusus kelas berdoa dan misi penjangkauan. ${ }^{34}$ Kuantitas dan kualitas tatap muka dengan konten-konten yang progresif, menarik, memberi tantangan dan pendampingan kekinian yang kontinyu. ${ }^{35}$ Jangan sekalipun merendahkan, menyepelekan bahkan menganggap generasi milenial seperti "kelas bawah" tanpa nilai namun hargai sebagai generasi penerobos, generasi gemilang, generasi anak panah masa depan dari gereja (Mzm 127:4).

Implikasi dari strategi ini adalah tentu berkurangnya jadwal dan kesempatan pelayanan untuk team senior lainnya. Bahkan kesempatan tamu dan undangan untuk melayani ditunda untuk sementara waktu. Pelayanan "kelas satu" yang biasanya dipegang oleh team senior dan pemimpin dalam gereja lokal bisa dipercayakan kepada anak milenial, seperti memimpin berdoa, berkotbah dan kesaksian. Hal ini seirama dengan pandangan Joni yang menyatakan dalam penelitiannya bahwa pemimpin pun harus mempunyai kemampuan untuk menjadi pelayan sejati di depan jemaatnya. ${ }^{36}$

Terobosan penggembalaan dalam hal komunikasi verbal visi dan misi atas berdampak semangat dan kerinduan Ilahi. Seperti penelitian Angie dan Ferry gembala dan para pemimpin gereja

\footnotetext{
${ }^{33}$ MSCI, "Millennials: Demographic Change and the Impact of a Generation," Thematic Insights (2020): 1-12, https://www.msci.com/documents/1296102/17292317/ThematicIndexMillenials-cbr-en.pdf/44668168-67fd-88cd-c5f7-855993dce7c4.

${ }^{34}$ Johannis Siahaya, "Misi Dalam Doa Yesus Menurut Yohanes 17," Jurnal Teruna Bhakti 1, no. 2 (2019): 64-74.

${ }^{35}$ Rumbiak, "Teologi Ibadah Dan Spiritualitas Generasi Milenial." (Batam, 2018).

${ }^{36}$ Joni Manumpak Parulian Gultom, Gembala: Antara Seorang Pelayan Dan Pemimpin
} 
lokal melakukan pendekatan komunikasi interpersonal yang hidup dan memberikan efektivitas dalam mengejawantahkan isi Firman Tuhan di generasi milenial yang terikat dengan minuman keras, judi dan pergaulan bebas. ${ }^{37}$ Penggembalaan menerima keberadaan mereka dengan peduli dan membangun komunikasi dengan tangan terbuka dan hangat. Kegiatan ini dilakukan dalam kasih di kehidupan sehari-hari. Hal hal yang dikomunikasikan bersifat ringan, saling menguatkan, membangun dan terlebih mengingatkan generasi milenial tentang Tuhan dan Firman-Nya.

Hal selanjutnya yang terjadi adalah melakukan kolaborasi, kerjasama dalam melayani. Kerjasama yang dimaksud di sini adalah bagaimana gembala dan pemimpin gereja bersama-sama dengan generasi milenial - termasuk didalamnya adalah anak anak jasmani mereka sendiri, bergabung bersama-sama dalam pelayanan yang ada. Tunjukkan kerjasama rohani dengan disengaja dan kebersamaan yang tinggi serta saling menghormati. Joseph Christ Santo menyatakan hal ini sebagai pengaruh keteladanan kerendahan hati yang murni sehingga dapat dilihat dan ditiru. ${ }^{38}$ Metode yang strategis dapat dilakukan seperti pelayanan dalam Pujian dan Penyembahan dan berdoa. Bila ada kesempatan, berikan kepercayaan kepada mereka untuk sharing Firman Tuhan dalam ibadah-ibadah tertentu seperti ibadah komunitas sel atau ibadah doa malam. Seluruh jemaat harus menyaksikan nilai kekompakan, kepercayaan dan kerendahan hari dari para senior untuk membagi panggung dengan para junior yang adalah anak milenial. Kesemuanya ini cepat atau lambat dapat memberikan efek unity yang sangat kuat dan tidak ada lagi pemisahan generasi dan eksklusif pelayanan.

Dan hal terakhir dan terpenting adalah kolaborasi dalam penjangkauan memenangkan jiwa. Bagaimana team pastoral dalam gereja lokal memberikan kepada mereka contoh dan dukungan penuh dalam motivasi dan meneguhkan panggilan Amanat Agung secara tegas dan jelas. Munthe menyatakan meski zaman dapat berubah, Amanat Agung tetap diberdayaakan dalam diri orang percaya. ${ }^{39}$ Irwan Widjaya menyatakan bahwa meskipun gereja sudah lebih 2000 tahun berdiri namun mandat Amanat Agung belum pernah selesai. Misi sebagai metode pengejewantahan Amanat Agung harus terus dilakukan apapun resikonya. ${ }^{40}$ Team pastoral mengingatkan anak milenial tentang misi dan penjangkauan jiwa - jiwa di komunitas, di sekolah, keluarga bahkan tempat tempat yang lain. Dan beri mereka ruang bahkan dalam komunitas virtual yang mereka miliki.

Team pastoral dan Gereja lokal harus memberikan waktu yang spesial, misalnya di Minggu pertama saat Perjamuan Kudus atau minggu minggu tertentu untuk tantangan panggilan misi Amanat

\section{${ }^{37}$ Angie Indria Kalesaran and Ferrry Koagouw, "Peranan Komunikasi Antar Pribadi} Pemimpin Pemuda Dalam Meningkatkan Minat Beribadah Pemuda GMIM Sion Warenbungan," Acta Diurna IV, no. 5 (2015): 1-12.

${ }^{38}$ Joseph Christ Santo and Dapot Tua Simanjuntak, "Pengaruh Keteladanan Hidup Gembala Sidang Terhadap Pertumbuhan Gereja," KHARISMATA: Jurnal Teologi Pantekosta 2, no. 1 (2019): $28-41$.

${ }^{39}$ Eben Munthe, "Mengopteamalkan Karunia Dalam Jemaat Untuk Melakukan Misi Amanat Agung Di Era 4.0," EPIGRAPHE: Jurnal Teologi dan Pelayanan Kristiani 3, no. 2 (2019): 133-141.

${ }^{40}$ Fransiskus Irwan Widjaja, Daniel Ginting, and Sabar Manahan Hutagalung, "Teologi Misi Sebagai Teologi Amanat Agung," Thronos 1, no. 1 (2019): 17-24. 
Agung, mereka didoakan dan mengutus mereka ke kehidupan sehari hari untuk penjangkauan jiwa jiwa. Tentu kelas - kelas misi dan penginjilan harus dibuka dalam persiapan awal untuk mengasah mentalitas supaya mengerti dan memahami tugas dan panggilan mereka. Berikan waktu secara spesial secara formal dalam ruang ibadah lokal atau pertemuan virtual untuk menyaksikan tentang pengalaman dan penjangkaun jiwa yang telah dilakukan, berikan penghargaan dan selamat untuk jiwa yang dituai buat Kristus. Banyak langkah untuk menghargai dan memberikan apresiasi seperti ucapan terimakasih, doa pengurapan ataupun dalam bentuk hadiah.

Kegerakan secara internasional dan lebih besar tentang tongkat estafet dan pemuridan menjadi contoh nilai nilai di atas salah satunya dalam pertemuan kegerakan Pantekosta di Jakarta. ${ }^{41}$ Dalam tema pertemuan Empowering 21 itu generasi milenial telah menjadi fokus pelayanan dari para pemimpin gereja-gereja dari 44 negara untuk mereka dipersiapkan menjadi penerus dan calon pemimpin gereja gereja di masa datang. Konsep dasarnya dengan bagaimana gembala senior memberikan legacy kepada anak kandungnya sendiri dari generasi milenial untuk melanjutkan pelayanan selanjutnya di gereja lokal mereka nanti. Tindakan lainnya adalah dengan tindakan terukur dan disengaja untuk membentuk team yang merekrut anak anak muda lewat kelas kelas spesial yang disesuaikan dengan kebutuhan gereja lokal seperti kelas kotbah, kepemimpinan, misi dan penginjilan dengan memenuhi kualifikasi persyaratan seperti umur pertobatan, karakter dan tanggung jawab. Berjalannya dengan waktu diharapkan mereka akan diberikan mimbar seluas luasnya dalam gereja lokal untuk ambil bagian dalam pelayanan di Ibadah Raya dan juga pertemuan pertemuan lainnya bahkan berperan aktif dalam struktur organisasi.

\section{Dunia Virtual dan Terobosan Strategi Penggembalaan}

Strategi dunia virtual adalah hal yang paling utama untuk dikerjakan khusus bagi generasi ini. Hal ini dikarenakan dunia digital sudah menjadi bagian hidup mereka sehari hari. Hampir seluruh elemen kehidupan mereka seperti pendidikan, hiburan, komunitas, kreativitas dan belanja secara native tapi tidak dengan hal hal religi. ${ }^{42}$ Keterlambatan gereja dalam kurun waktu belakangan ini menjadi tugas berat di masa sekarang untuk "memaksa" mereka memberikan ruang hati bagi sisi kerohanian. Hal ini dapat dilakukan dengan penggunaan ruang dalam dunia digital transeden. ${ }^{43}$ Diperlukan metode dan langkah yang penuh hikmat untuk membawa generasi muda ini dalam mengimajinasikan kehidupan kekristenan itu secara nyata dan berkualitas tinggi dalam ruang digital. Era society 5.0 menghadirkan monitoring secara langsung kepada mereka.

\section{Pantekosta."}

\section{${ }^{41}$ Gultom et al., "Generasi Millenial Dan Kaitan Tugas Yeremia Dalam Kegerakan}

${ }^{42}$ Ester, "Mengenal Generasi Millennial."

${ }^{43}$ Mick Mordekhai Sopacoly and Izak Y.M. Lattu, "Kekristenan Dan Spiritualitas Online: Cybertheology Sebagai Sumbangsih Berteologi Di Indonesia," Gema Teologika : Jurnal Teologi Kontekstual dan Filsafat Keilahian 5, no. 2 (2020): 137-154. 
Proses secara adaptif dan transformatif tetap menjadi konsep utama, sesuatu yang lahiriah masih dianggap bermakna. ${ }^{44}$ Hal ini tidaklah mudah, karena diperlukan waktu dan narasi rohani dengan nilai kekekalan yang dirasakan kuat buat mereka (Yoh 16:13; Rm 1:17). Hal ini juga oleh Afandi dikaitkan dengan bagaimana nilai-nilai kerohanian dalam gereja secara konservatif yang bersifat tatap langsung namun sekarang seperti diajarkan untuk bisa diterima oleh generasi milenial dalam nilai kualitas rohani yang identik dalam media virtual. ${ }^{45}$ Namun team penggembalaan dapat melakukannya dengan impartasi dan monitoring evaluasi secara berkala dalam kelompok kelompok kecil di antara mereka. Sebutkan dua minggu sekali, berjenjang kepada satu bulan sekali dan seterusnya

Memang ada tantangan dan diperlukan keterampilan metakognitif serta skill dari team pastoral yang ada. Dan ini semua memerlukan hati untuk belajar dan meng upgrade diri sendiri.

Monitoring dan evaluasi rohani dengan mengajak berdoa bersama sungguh-sungguh, mendengarkan Firman Tuhan yang penuh otoritas, komunitas sel, kesaksian dan penyembahan dalam ruang virtual. Hal penting dalam pelayanan rohani menggunakan media sosial adalah membangun ibadah menjadi lebih dekat dan terhubung dengan mereka. Implikasi penggunaan media adalah pertemuan dan ibadah bisa dilakukan fleksibel untuk kegiatan berdoa, bible study atau komunitas sel digital.

Anggotanya tidak terbatas dan bersifat sangat luas. Siapapun bisa bergabung dan mengambil bagian secara aktif. Diperlukan keterbukaan dan komunikasi ramah, hangat dari para gembala saat melayani mereka dalam ruang digital. Hal pokok dan yang terpenting dalam ruang virtual ini adalah fokuskan pelayanan dalam kelas kelas kepemimpinan gereja (church leadership). Bagaimana pola pemuridan dan mentoring bisa berjalan bersama-sama dalam ruang virtual dengan nilai rohani yang tinggi. Bagaimana membangun komitmen dan konsistensi penggembalaan dalam berdoa pagi, komunitas sel khusus untuk pengerja, doa pengerja di rumah masing masing dalam ruang media virtual. Namun para pemimpin gereja melihat secara aktif generasi ini dapat mengontrol kehadiran mereka secara langsung dan melihat respon respon positif dalam pertemuan ibadah online yang dihasilkan. ${ }^{46}$

Pelayanan penggembalaan ruang virtual harus sederhana dan mudah dimengerti dengan penggunaan waktu singkat namun berulang-ulang secara kontinyu dapat menjadi lebih maksimal. Menurut data orang Indonesia menggunakan media sosial rata rata 3 jam 14 menit/ hari. Bila dikaitkan dengan pengguna media sosial dalam pelayanan gereja maka mereka termasuk ke dalam konsep pelayanan mystical communion, yaitu model gereja yang sangat relevan dengan komunitas digital yang terbentuk dan beragam, demokratis dan sesama anggota lebih erat. Tidak ada hirarkis kaku dan

\footnotetext{
${ }^{44}$ Cabinet Office, "Society 5.0," Cabinet Office, Goverment of Japan, last modified 2019, https://www8.cao.go.jp/cstp/english/society5_0/index.html.

${ }^{45}$ Yahya Afandi, "Gereja Dan Pengaruh Teknologi Informasi 'Digital Ecclesiology," Fidei: Jurnal Teologi Sistematika dan Praktika 1, no. 2 (2018): 270-283.

${ }^{46}$ Ibid.
} 
doktrin ketat yang cenderung menghambat. Dalam keadaan ini semua kemampuan digital eklesiologi menjadi nilai yang ditanamkan kepada generasi ini untuk mengopteamalkan bayangan dan imajinasi religius mereka yang terarah menembus kesatuan rohani dengan teknologi mutakhir. ${ }^{47}$

Yesus pernah mengatakan untuk murid murid-Nya berjaga-jaga satu jam lamanya supaya tidak jatuh dalam pencobaan (Mat 26:40). Durasi waktu satu jam bisa digunakan sebagai acuan standar penggembalaan ruang virtual dengan waktu tertentu. Problem klasik adalah keterbatasan biaya kuota internet. Namun penatalayanan penggembalaan virtual harus dapat memberikan nilai hakiki, solusi, kekuatan dan pendampingan rohani. Hal yang tidak boleh dianggap remeh adalah bagaimana team penggembalaan menjadi contoh dan memegang peranan penting dalam setiap pertemuan rohani. Kerendahan hati harus ditonjolkan sebaik mungkin dengan memulai pembicaraan, menanyakan kabar sampai isu isu yang menjadi kesukaan anak milenial, karena hal hal ini menjadi bahan dinamis yang selalu dapat dikaitkan dengan materi materi khotbah atau sharing yang disampaikan (Kol 3:12; Fil 2:3). Komunikasi dua arah dalam ruang virtual yang hangat dan terbuka menjadi kebutuhan utama generasi milenial. Bagaimana menggugah hati dan memberikan memberikan kesempatan kepada mereka untuk memberikan ide dan narasi narasi yang ingin mereka sampaikan secara lugas tanpa merasa dilecehkan atau direndahkan. Dikarenakan komunikasi anak milenial dapat merasa lebih leluasa dan ringan serta maksimal apabila menyampaikan sesuatu dengan media sosial yang dikuasainya.

\section{KESIMPULAN}

Para gembala dan pemimpin gereja harus mengambil strategi yang berbeda sekarang ini dalam penjangkauan anak milenial dengan melakukan kombinasi pelayanan. Metode dan pola penggembalaan gereja lama kehilangan kekuatan untuk dapat menyatukan sisi rohani anak milenial dengan teknologi mutakhir dunia digital yang menjadi kekuatan mereka. Ibadah dan pertemuan tatap muka tetap menjadi kegiatan utama namun dengan konten visi dan misi khusus anak milenial yang berkaitan dengan dunia dan kehidupan mereka. Persiapakan ruang dan kesempatan untuk pelayanan generasi milenial di banyak sector bahkan sampai menjadi pengkotbah dan pemimpin dari gereja lokal. Hadirkan dan promosikan mereka dalam Ibadah Raya dan pertemuan rohani secara konsisten dalam waktu waktu tertentu. Kreativitas dan ide inovatif menjadi bagian yang selalu update dalam penyajian konten kotbah, kesaksian, ibadah dan lain sebagainya. Pemanfaatan media sosial dengan konten berdoa, kesaksian dan pemuridan serta hal hal penting dalam kehidupan anak milenial menjadi fokus para gembala dan pemimpin gereja lokal. Namun yang terpenting adalah dukungan dan motivasi dari team penggembalaan khususnya dan jemaat lokal buat mereka.

\footnotetext{
${ }^{47}$ Yahya Afandi, “Gereja Dan Pengaruh Teknologi Informasi ‘Digital Ecclesiology.
} 


\section{DAFTAR PUSTAKA}

Afandi, Yahya. "Gereja Dan Pengaruh Teknologi Informasi 'Digital Ecclesiology." Fidei: Jurnal Teologi Sistematika dan Praktika 1, no. 2 (2018): 270-283.

Alex Arifianto, Yonatan, Sari Saptorini, and Kalis Stevanus. "Pentingnya Peran Media Sosial Dalam Pelaksanaan Misi Di Masa Pandemi Covid-19.” Harvester 5, no. 2 (2020): 86-104.

Darmawan, I Putu Ayub. “Jadikanlah Murid: Tugas Pemuridan Gereja Menurut Matius 28:18-20.” Evangelical 3, no. 2 (2019): 144-153.

Day, Abby. Religion and the Individual: Belief, Practice, Identity. Religion and the Individual: Belief, Practice, Identity, 2016.

Ester. "Mengenal Generasi Millennial.” Kementerian Informasi Dan Informatika Republik Indonesia. Last modified 2016. https://www.kominfo.go.id/content/detail/8566/mengenal-generasimillennial/0/sorotan_media.

Gultom, Joni Manumpak Parulian. Gembala: Antara Seorang Pelayan Dan Pemimpin. Batam, 2018.

Gultom, Joni Manumpak Parulian, Ferdinandes Petrus Bunthu, Francois Pieter Tomasoa, and Foera Era Nduru. "Generasi Millenial Dan Kaitan Tugas Yeremia Dalam Kegerakan Pantekosta." Real Didache 4, no. 1 (2019): 12-25.

Handi Irawan D, Cemara A. Putra. "Gereja Sudah Tidak Menarik Bagi Kaum Muda, [The Church Is Not Attractive To Young People]." Bilangan Research Center. Last modified 2018. Accessed July 31, 2021. http://bilanganresearch.com/gereja-sudah-tidak-menarik-bagi-kaum-muda.html.

Hasanah, Hasyim. "Teknik-Teknik Observasi.” at-Taqaddum 8, no. 1 (2016): 21-46.

Hidayat, M. "Ini Perbedaan Revolusi Industri 4.0 Dengan Society 5.0.” Liputan6.Com. Last modified 2020. Accessed July 31, 2021. https://www.liputan6.com/tekno/read/4408526/ini-perbedaanrevolusi-industri-40-dengan-society-50.

Indria Kalesaran, Angie, and Ferrry Koagouw. "Peranan Komunikasi Antar Pribadi Pemimpin Pemuda Dalam Meningkatkan Minat Beribadah Pemuda GMIM Sion Warenbungan.” Acta Diurna IV, no. 5 (2015): 1-12.

Irawan, Handi. “Spiritualitas Umat Kristen Indonesia 2021.” Bilangan Research Center. Jakarta, 2021.

Kinnaman, David, and Aly Hawkins. You Lost Me, Why Young Christians Are Leaving Church and Rethinking Faith. Michigan: Baker Books, 2011. https://www.yumpu.com/en/document/view/64143544/download-pdf-you-lost-me-why-youngchristians-are-leaving-church-and-rethinking-faith-full-online/3.

Kvande, Marianne Nilsen, Christian Andreas Klöckner, and Michael E Nielsen. "Church Attendance and Religious Experience : Differential Associations to Well- Church Attendance and Religious Experience : Differential Associations to Well-Being for Norwegian Women and Men ?," no. November (2015): 1-13.

Magdalena, Yanto Paulus Hermanto, and Ferry Simanjuntak. "Gereja Yang Bertumbuh Tanpa Baalisme." Voice Of Wesley 4, no. 2 (2019): 11-23.

Mulawarman, and Aldila Dyas Nurfitri. "Perilaku Pengguna Media Sosial Beserta Implikasinya Ditinjau Dari Perspektif Psikologi Sosial Terapan.” Buletin Psikologi 25, no. 1 (2017): 36-44. 
Munthe, Eben. "Mengoptimalkan Karunia Dalam Jemaat Untuk Melakukan Misi Amanat Agung Di Era 4.0." EPIGRAPHE: Jurnal Teologi dan Pelayanan Kristiani 3, no. 2 (2019): 133-141.

Negoita, Alexandru Gabriel. "Religiosity In The Contemporary World." Euromentor X, no. 3 (2019): 27-38.

Ni Nyoman Lisna Handayani1, Ni Ketut Erna Muliastrini2. "Pembelajaran Era Disruptif Menuju Era Society 5.0 (Telaah Perspektif Pendidikan Dasar) Ni." International Seminar Proceeding 3, no. 2252 (2020): 58-66.

Office, Cabinet. “Society 5.0.” Cabinet Office, Goverment of Japan. Last modified 2019. https://www8.cao.go.jp/cstp/english/society5_0/index.html.

Root, Andrew. "Stop Worrying about the Millennials*:*and Learn to Love Them Instead." Christianity Today 59, no. 1 (2015): 30-36.

Rumbiak, Amelia Kimberlyann. "Teologi Ibadah Dan Spiritualitas Generasi Milenial.” Amreta 3, no. 2 (2020): 64-100.

Sagala, Lenda Dabora J F. "Tugas Pedagogis Gembala Dalam Menyiapkan Warga Gereja Menghadapi Perubahan Sosial.” Evangelikal: Jurnal Teologi Injili dan Pembinaan Warga Jemaat 4, no. 2 (2020): 167-174.

Santo, Joseph Christ, and Dapot Tua Simanjuntak. "Pengaruh Keteladanan Hidup Gembala Sidang Terhadap Pertumbuhan Gereja.” KHARISMATA: Jurnal Teologi Pantekosta 2, no. 1 (2019).

Sapan, Sara L, and Dicky Dominggus. "Tanggung Jawab Penggembalaan Berdasarkan Perspektif 1 Petrus 5: 1-4" 3, no. 2 (2020): 1-4.

Siahaya, Johannis. "Misi Dalam Doa Yesus Menurut Yohanes 17." Jurnal Teruna Bhakti 1, no. 2 (2019): 64-74.

Sirait, Bigman. "Ritual Tanpa Spritual.” Reformata. Last modified 2015. https://reformata.com/news/view/370/ritual-tanpa-spritual.

Sopacoly, Mick Mordekhai, and Izak Y.M. Lattu. "Kekristenan Dan Spiritualitas Online: Cybertheology Sebagai Sumbangsih Berteologi Di Indonesia." Gema Teologika : Jurnal Teologi Kontekstual dan Filsafat Keilahian 5, no. 2 (2020): 137-154.

Surya Putra, Yanua. “Teori Perbedaan Generasi.” Among Makarti 9, no. 18 (2016): 123-134.

Sutaryo. Sosiologi Komunikasi. Universitas Terbuka. Jakarta: Universitas Terbuka, 2005. http://repository.ut.ac.id/4614/2/SOSI4402-M1.pdf.

Tafonao, Talizaro. "Yesus Sebagai Guru Teladan Dalam Masyarkat Berdasarkan Perspektif Injil Matius." Khazanah Theologia 2, no. 1 (2020): 52-60.

Widjaja, Fransiskus Irwan, Daniel Ginting, and Sabar Manahan Hutagalung. "Teologi Misi Sebagai Teologi Amanat Agung." Thronos 1, no. 1 (2019): 17-24.

Wulan Sari, Ambar. "Pentingnya Ketrampilan Mendengar Dalam Menciptakan Komunikasi Yang Efektif." Jurnal EduTech 2, no. 1 (2016): 1-10. http://jurnal.umsu.ac.id/index.php/edutech/article/view/572. 